\title{
Effect on the Influence of Watering Rate and the Type of Substrate on the Production of Tomatoes (Lycopersicon Esculentum Mill.) Grown in the Greenhouse in Unconventional System
}

\author{
Ionuţ Ovidiu JERCA*, Sorin Mihai CÎMPEANU and Elena Maria DRĂGHICI
}

University of Agronomic Sciences and Veterinary Medicine of Bucharest, 59 Mărăşti Blvd, District 1, 011464, Bucharest, Romania, Phone: +4021.318 .25 .64 , Fax: +4021.318 .25 .67$

*)Corresponding author, e-mail: jerca_ovidiu@yahoo.com

BulletinUASVM Horticulture 73(1) / 2016

Print ISSN 1843-5254, Electronic ISSN 1843-5394

DOI:10.15835/buasvmcn-hort:11414

\begin{abstract}
The study followed the influence of irrigation rate on early and total yields of tomatoes (Lycopersicon esculentum Mill.) grown in unconventional system, on different types of substrate. Purpose of the study was to recommend variant with lowest cost for irrigation rate to make an early and total production more efficient. The study was carried out in the greenhouse, using the biological material hybrid Cyndel grown on three types of substrate (perlite, mineral wool, cocopeat). We applied three watering rates and have been carried out on biometrical measurements dynamic plant growth, inflorescence formation. Has been registered early and total production for each variant of substrate and watering rate the highest yields were obtained at V3 (119.43 t/ha) at which was apply watering rate $b\left(6560 \mathrm{~m}^{3} / \mathrm{ha}\right)$. The results showed differences between variants, both with regard to plant height, and the total production in comparison with the rate of irrigation. When using mineral wool and cocopeat substrates were recorded plant height compared with variants that have used perlite.
\end{abstract}

Keywords: Substrate, tomato, watering rate.

\section{INTRODUCTION}

The production of tomatoes has an important place in greenhouses, and water consumption is one of the factors to be taken into account in the context of its savings. One of the best performing technologies of tomato growing is the soilless culture on different types of substrates. The type of substrate and the use of organic fertilizers may lead to large, high quality crops, Drăghici et al. (2013). Majid Fandi et al. (2008) and contributors recommend the use of tuff or sand in order to save water and increase the tomato crop yield. The growing medium used in container culture must have good nutrient- and water- holding characteristics, and provide good aeration to the root system. Soilless culture is an effective tool to increase crop yield and, if closed irrigation systems are adopted, to reduce the environmental impact of greenhouses and nurseries Pardossi et al. (2011). Reduction in fruit yields and/or physiological disorders, such as blossom - end rot, caused by the unbalanced nutrient solution of the wastewater effluents, could be corrected merely by adjusting the concentration of nutrients. Thus, reusing treated wastewater effluents may have positive effects on saving ordinary irrigation water and commercial fertilizers as well as preserving the environment from the nutrients that cause eutrophication Traka-Mavrona et al. (1998).

Aims: In the context of water saving irrigation, we tried to identify the most economical variant of fertigation, which offer the highest production, according with the type of substrate on the tomatoes crop.

\section{MATERIALS AND METHODS}

The study was conducted in the greenhouses belonging to the Hortinvest research center, 
belonging to the USAMV Bucharest, in the period of 2014-2015.The biological material used in the experiment was the cultivar Cyndel F1. The culture was conducted in an unconventional system, on nutrient mattresses, the experimental variants are presented in table 1 . The cultivated area in the greenhouse was $162 \mathrm{~m}^{2}$.

All environmental factors were programmed by computer. In the greenhouse was maintain a temperature of $22^{\circ} \mathrm{C}$ in the day and $18^{\circ} \mathrm{C}$ in the night. Have been applied three watering norms according to the experimental plan, presented in table 1.

The culture was established with transplants produced in the greenhouse within 45 days. They were produced on nutrient mattresses, according to the plan. Every mattress had 3 plants on it. The length of each mattress was of $1 \mathrm{~m}$, and the capacity was of $30 \mathrm{l}$, namely $15 \mathrm{l}$ of substrate.

After the planting, several care works were conducted, which consisted in: timing, cutting the sprouts, tipping plants and lowering them. The additional pollination was conducted with the help of the bumblebees. Biological prevention was applied to the culture.

The nutritive formula was modified according to the vegetation phenolphase. The EC was different from 1.5 to 3.5 and the $\mathrm{pH}$ was maintained at the value of 5.5 .

The following determinations were conducted: the record of the tomato plant's growth for each variant, the number of inflorescence and the established crops. Several correlations were conducted between the parameters.

The purpose of this study was to estimate the early and total production, depending on the doses of the applied nutrient solutions.

All assays were carried out in triplicate. Results have been statistical interpreted by variance analysis (ANOVA) for $\mathrm{p}<0.05$, according to Student test.

\section{RESULTS AND DISCUSSION}

We observed that the height of the plants at 110 days after the planting was in the range of $257.7 \mathrm{~cm}$ on the variant grown on mineral wool substrate and of only $220.4 \mathrm{~cm}$ on the variant 5 , grown on perlite mattresses of $5 \mathrm{~mm}$ with a volume of $30 \mathrm{l}$. In the case of all the variants grown on perlite substrate and watered with the smallest watering rate $a$ the plants height was under the values of the ones grown on mineral wool and cocopeat (Jiffy).

In the case of $b$ watering variant we have observed that the height of the plants was bigger relative to variant $a$. The biggest height was obtained on V2 on cocopeat (Jiffy) substrate, where the plants had a height of $286.2 \mathrm{~cm}$. The smallest height was obtained on V5 on $5 \mathrm{~mm}$ perlite substrate with a volume of $30 \mathrm{l}$, figure

In the case of the variant in which we have applied the $c$ watering rate, we have noticed that V1 and V2 on mineral wool and cocopeat substrate have presented the biggest growth of $283.4 \mathrm{~cm}$

Tab. 1. Experimental variants used in the experiment.

\begin{tabular}{|c|c|c|c|c|c|c|c|}
\hline \multirow[b]{2}{*}{ Variant } & \multirow[b]{2}{*}{ Type of substrate } & \multicolumn{3}{|c|}{ Amount of substance } & \multirow{2}{*}{$\begin{array}{l}\text { Growing } \\
\text { location }\end{array}$} & \multirow{2}{*}{\multicolumn{2}{|c|}{ Period }} \\
\hline & & $\begin{array}{c}\text { (norm a) } \\
\mathrm{m}^{3} / \mathrm{ha}\end{array}$ & $\begin{array}{c}\text { (norm b) } \\
\mathrm{m}^{3} / \mathrm{ha}\end{array}$ & $\begin{array}{c}\text { (norm c) } \\
\mathrm{m}^{3} / \mathrm{ha}\end{array}$ & & & \\
\hline V1 & Mineral wool & 4640 & 6560 & 9280 & Greenhouse & $\begin{array}{c}\text { February, } \\
\text { July } 15\end{array}$ & 2014-2015 \\
\hline V2 & Cocopeat (Jiffy) & 4640 & 6560 & 9280 & Greenhouse & $\begin{array}{l}\text { February, } \\
\text { July } 15\end{array}$ & 2014-2015 \\
\hline V3 & $\begin{array}{c}\text { Perlite } 4 \mathrm{~mm} \\
\text { mattresses of } 30 \mathrm{l}\end{array}$ & 4640 & 6560 & 9280 & Greenhouse & $\begin{array}{c}\text { February, } \\
\text { July } 15\end{array}$ & 2014-2015 \\
\hline V4 & $\begin{array}{c}\text { Perlite } 4 \mathrm{~mm} \\
\text { mattresses of } 15 \mathrm{l}\end{array}$ & 4640 & 6560 & 9280 & Greenhouse & $\begin{array}{c}\text { February, } \\
\text { July } 15\end{array}$ & 2014-2015 \\
\hline V5 & $\begin{array}{c}\text { Perlite } 5 \mathrm{~mm} \\
\text { mattresses of } 30 \mathrm{l}\end{array}$ & 4640 & 6560 & 9280 & Greenhouse & $\begin{array}{c}\text { February, } \\
\text { July } 15\end{array}$ & 2014-2015 \\
\hline V6 & $\begin{array}{c}\text { Perlite } 5 \mathrm{~mm} \\
\text { mattresses of } 15 \mathrm{l}\end{array}$ & 4640 & 6560 & 9280 & Greenhouse & $\begin{array}{c}\text { February, } \\
\text { July } 15\end{array}$ & 2014-2015 \\
\hline
\end{tabular}


on V2 and of $268.4 \mathrm{~cm}$ on V1. The smallest plant growth was obtained on V5 of about $230.00 \mathrm{~cm}$ (figure 3).

In the case of watering rate $a$ the date regarding height of the tomato plants are shown in Table 2 . We found that the height of the tomato plants was under V1- control. These data are supported statistically significantly negative experience is very significant.

Where the norm of watering rate $b$ were recorded statistically very significant negative differences for variant 3 and negative very significant at V4, V5 and V6 against the variant 1 taken as a control (Tab. 3).

In the case in which we applied the watering rate $c$ was found that there were differences in plant height depending on the type of substrate. The greatest plant height was recorded at V2 $(279.81 \mathrm{~cm})$ sustained statistical the difference from control V1 was significantly distinct. For V3, $\mathrm{V} 4$ and V 5 were recorded negative very significant differences (Tab. 4).

Analyzing the growth of the tomato plants grown on mineral wool substrate we have noticed that there was a positive relationship regarding the increased watering norm. The relation that was obtained between the plant's height and the watering norm was equal to $\mathrm{R}^{2}=0.7435$ in the case of mineral wool substrate (figure 4).

In the case of cocopeat substrate, we have also observed that the watering norm has favoured the growth of the plants. The relation that was

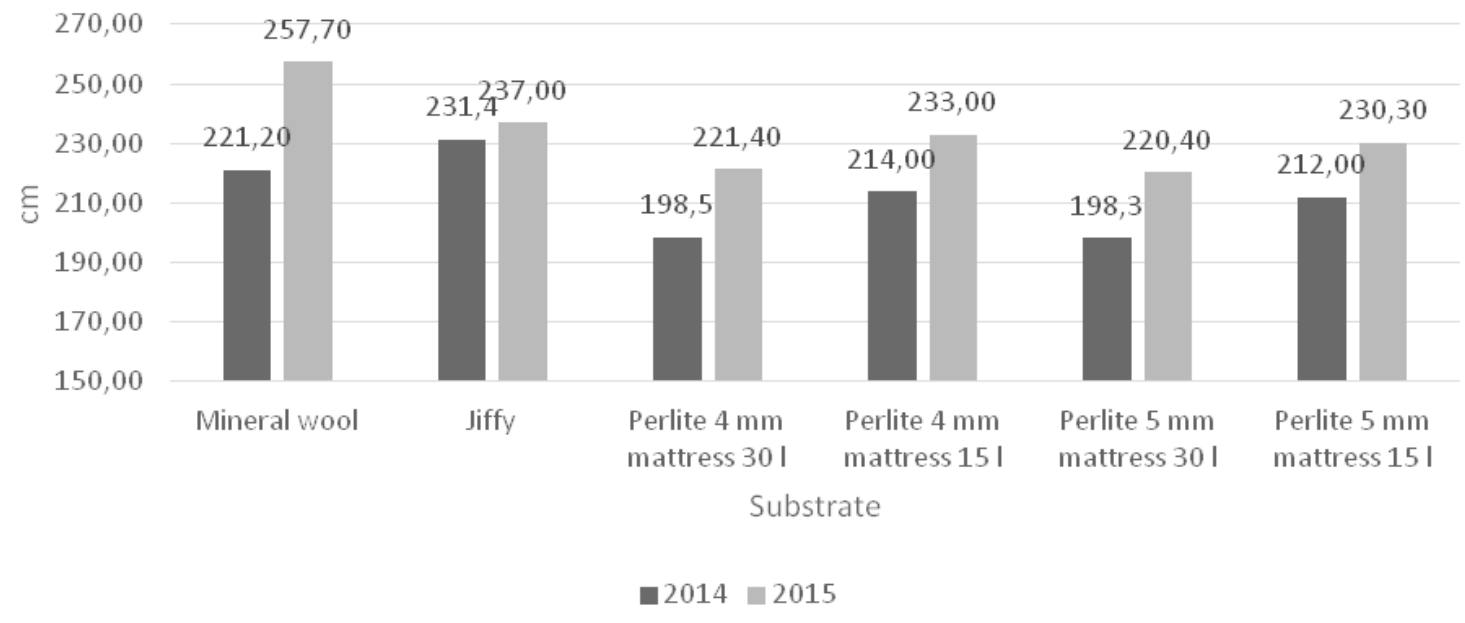

Fig. 1. The growth dynamics of tomato plants- Cyndel hybrid, variants in which norm $a$ was administrated

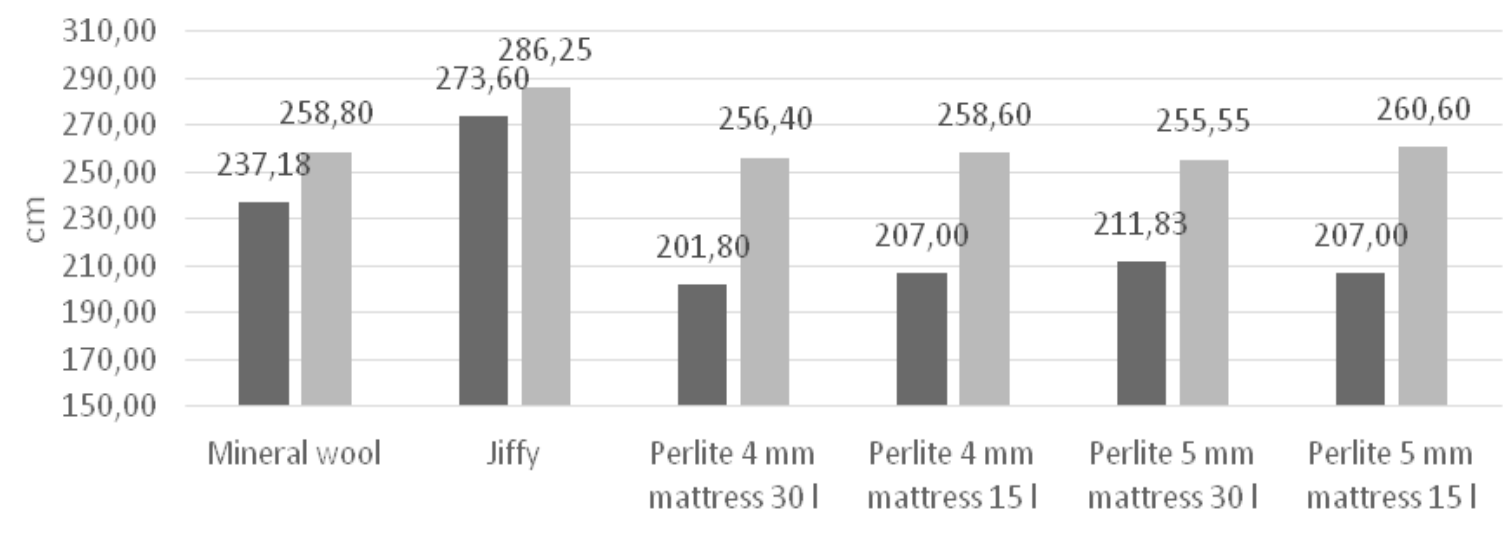

substrate

Fig. 2. The growth dynamics of tomato plants - greenhouse Cyndel hybrid - 2014-2015, in the case of the $b$ watering rate 
obtained after the correlation between the plant's height and the watering norm was conducted was of $\mathrm{R}^{2}=0.8739$ (figure 5).

In the figures 6 and 7 we can notice that on the variant grown on $4 \mathrm{~mm}$ perlite substrate there was a very weak correlation between the watering norm and the plants' height. In the case of this type of substrate, the administered nutrient solution didn't have an influence upon the vegetative growth.

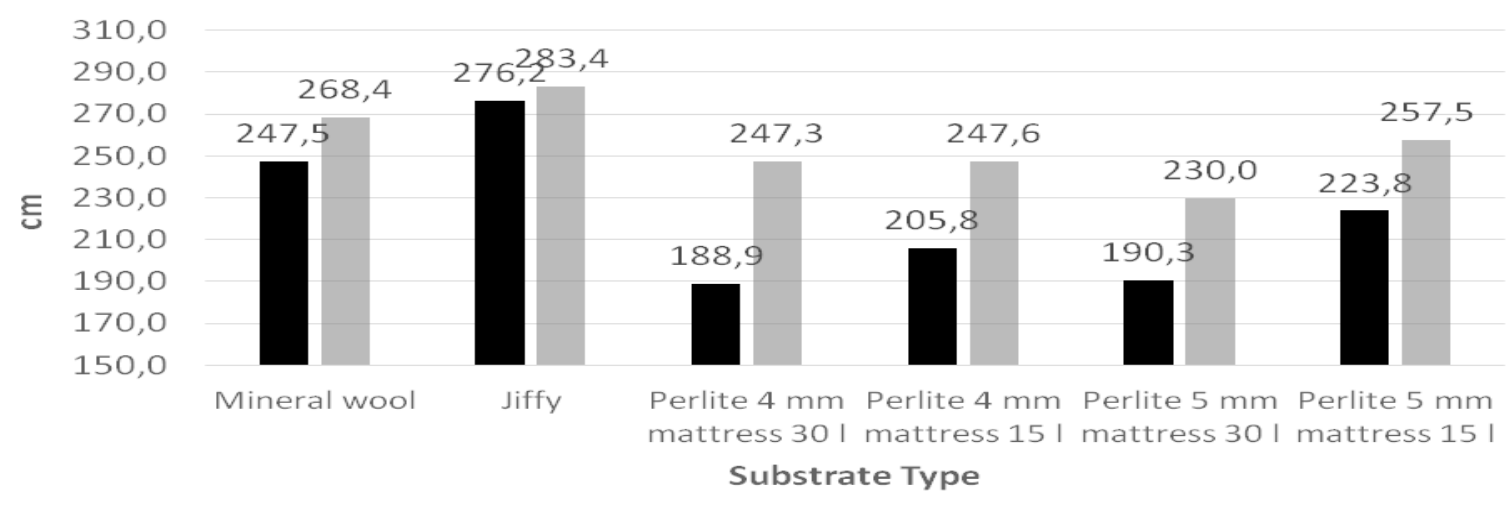

$2014-2015$

Fig. 3. The growth dynamics of tomato plants- greenhouse Cyndel hybrid - 2014-2015, in the case of the $c$ watering rate

Tab. 2. The synthesis of the plant height - in the case of $a$ watering rate (average 2014-2015)

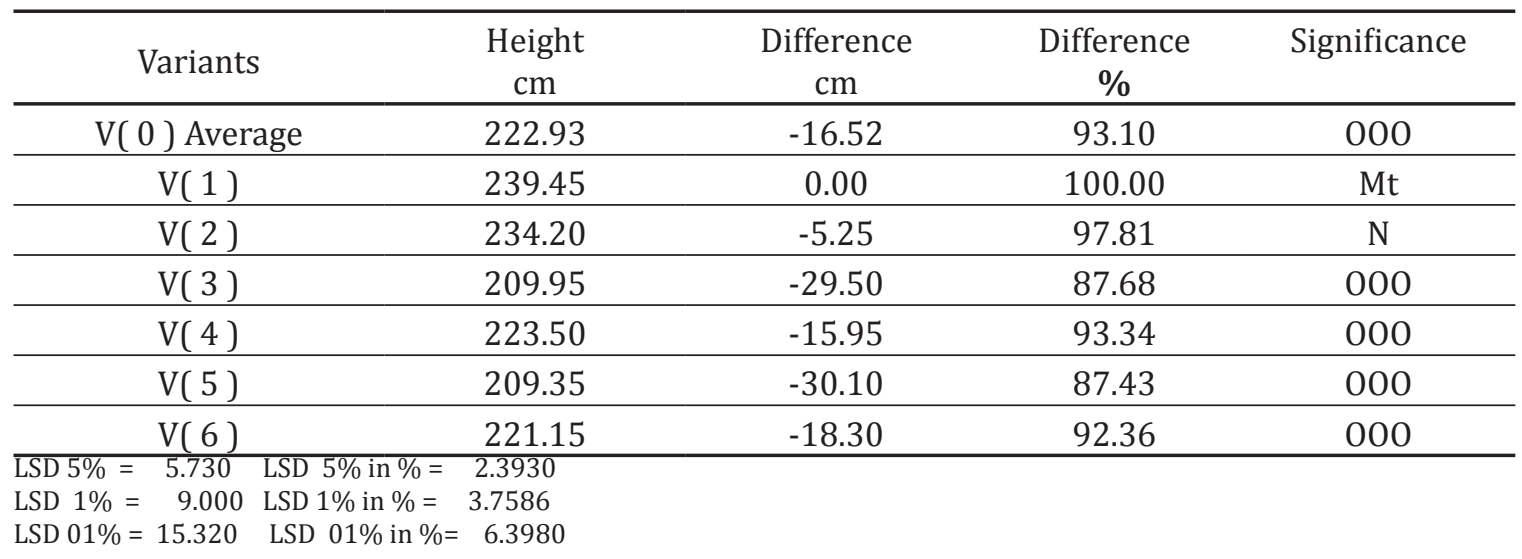

Tab. 3. The synthesis of the plant height - in the case of $b$ watering rate (average 2014-2015)

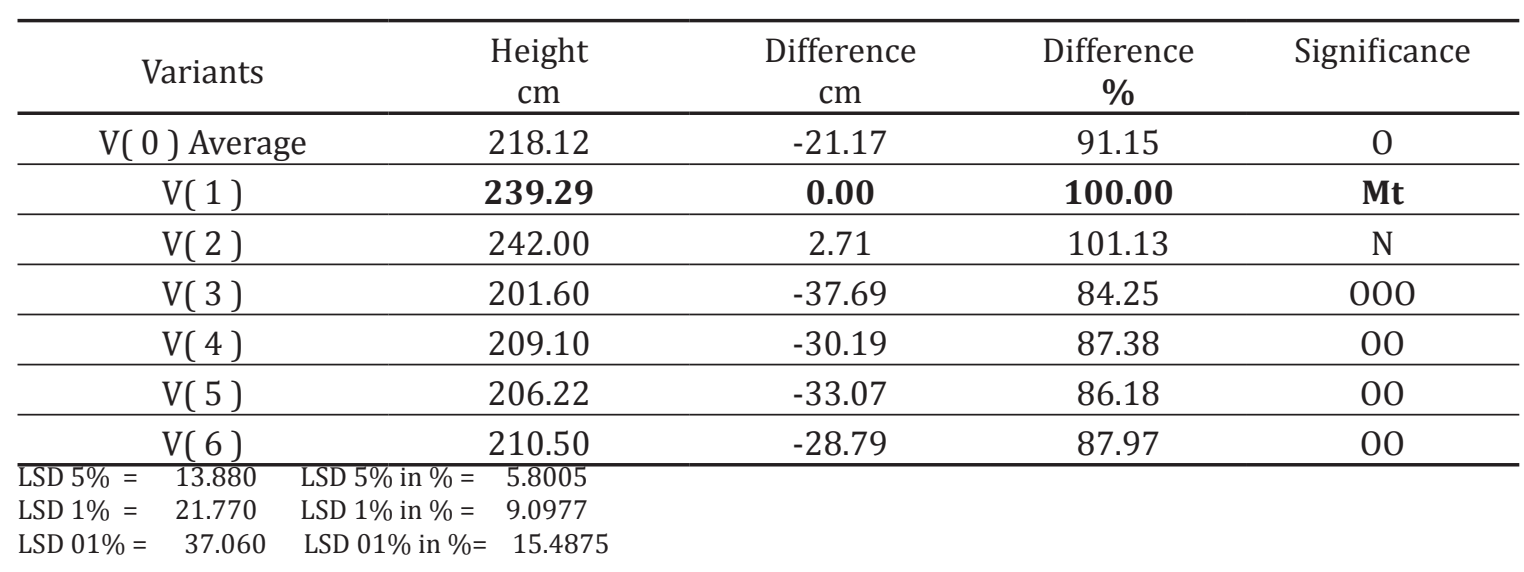


The production data have shown that there were important differences between the total productions obtained according to the used watering norm. The smallest productions have been obtained in the case where $a$ watering norm was applied. The biggest total production has been obtained on the variant where $b$ watering norm was applied (figure 10).

In figures 11 and 12 correlations between the established productions and the watering norm according to the type of substrate are presented. We can notice that the watering norm has

Tab. 4. The synthesis of the plant height - in the case of $c$ watering rate (average 2014-2015)

\begin{tabular}{ccccc}
\hline Variants & $\begin{array}{c}\text { Height } \\
\mathrm{cm}\end{array}$ & $\begin{array}{c}\text { Difference } \\
\mathrm{cm}\end{array}$ & $\begin{array}{c}\text { Difference } \\
\text { \% }\end{array}$ & Significance \\
\hline $\mathrm{V}(0)$ Average & 238.89 & -19.06 & 92.61 & 00 \\
\hline $\mathrm{V}(1)$ & 257.95 & 0.00 & 100.00 & $\mathrm{Mt}$ \\
\hline $\mathrm{V}(2)$ & 279.81 & 21.86 & 108.47 & $* * *$ \\
\hline $\mathrm{V}(3)$ & 218.10 & -39.85 & 84.55 & 000 \\
\hline $\mathrm{V}(4)$ & 226.70 & -31.25 & 87.89 & 000 \\
\hline $\mathrm{V}(5)$ & 210.15 & -47.80 & 81.47 & 000 \\
\hline $\mathrm{V}(6)$ & 240.65 & -17.30 & 93.29 & 00 \\
\hline LSD 5\% $=7.200$ & LSD 5\% in \%= 2.7912 & & & \\
LSD 1\% $=$ & 11.300 & LSD 1\% in $\%=4.3807$ & & \\
LSD 01\% $=19.240$ & LSD 01\% in \%= 7.4588 & & &
\end{tabular}

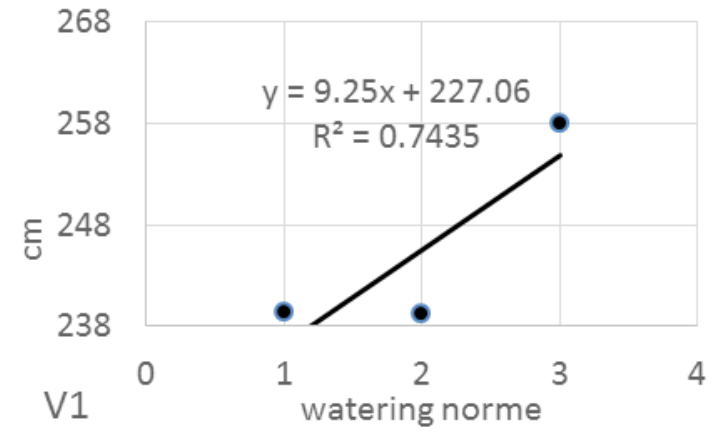

Fig. 4. The correlation between the plants' height and watering norm $(a, b, c)$ on tomato crop mineral wool substrate, average of 2014-2015

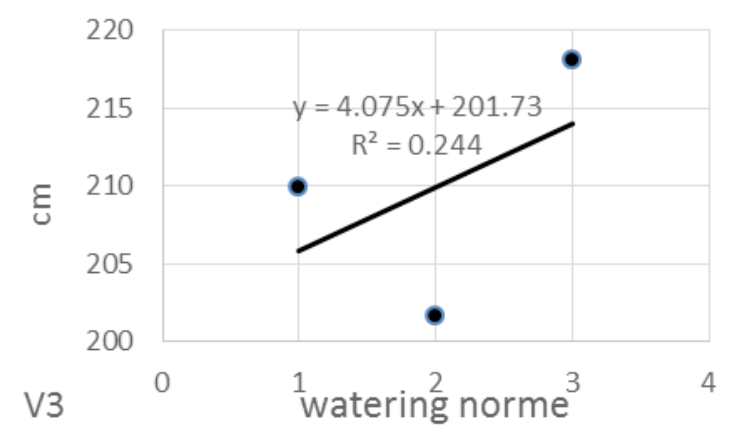

Fig. 6. The correlation between the plants' height and the watering norm $(a, b, c)$ on tomato crop - $4 \mathrm{~mm}$ Perlite substrate on mattresses of 301 , average of 2014-2015

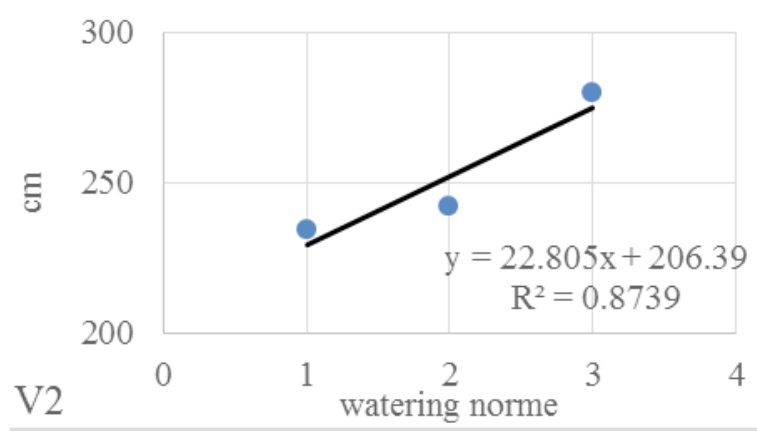

Fig. 5. The correlation between the plants' height and watering norm $(a, b, c)$ on tomato crop cocopeat substrate, average of 2014-2015

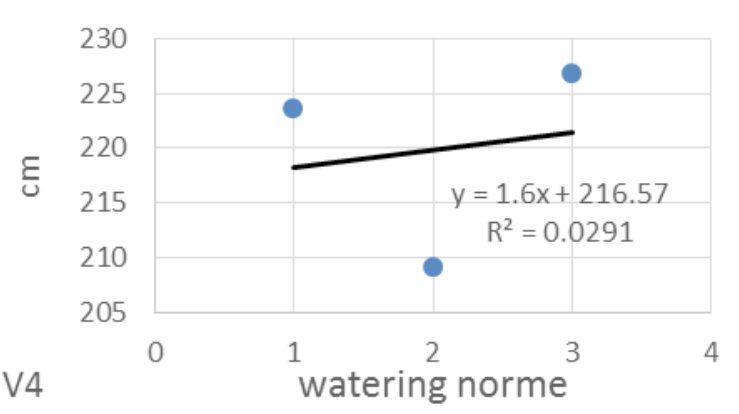

Fig. 7. The correlation between the plants' height and the watering norm $(a, b, c)$ on tomato crop - $4 \mathrm{~mm}$ Perlite substrate on mattresses of $15 \mathrm{l}$, average of 2014-2015 
influenced the production, therefore the relations are: $\mathrm{R}^{2}=0.6081$ in the case of the $a$ watering rate, $\mathrm{R}^{2}=0.8239$ in the case of the $b$ watering rate and $\mathrm{R}^{2}=0.3357$ in the case of the $c$ watering rate.

Analyzing the total production obtained in the greenhouse for the norm, we found that the lowest

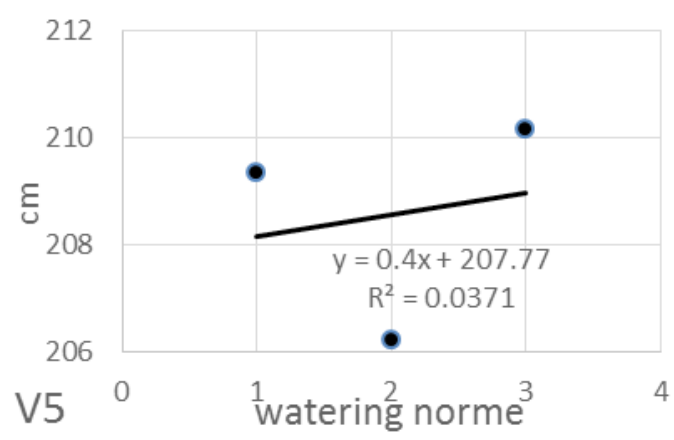

Fig. 8. The correlation between the plants' height and the watering norm $(a, b, c)$ on tomato crop - $5 \mathrm{~mm}$ Perlite substrate on mattresses of 301 , average of 2014-2015 overall yield was recorded at V6 (101.87 t /ha) with $3.11 \mathrm{t} /$ ha less than the V1 - control (101.87 $\mathrm{t} / \mathrm{ha}$ ). The highest total production was recorded at V3 (106.04 t /ha) with $1.06 \mathrm{t} /$ ha over control V1. The differences were statistically significant (Tab. 5).

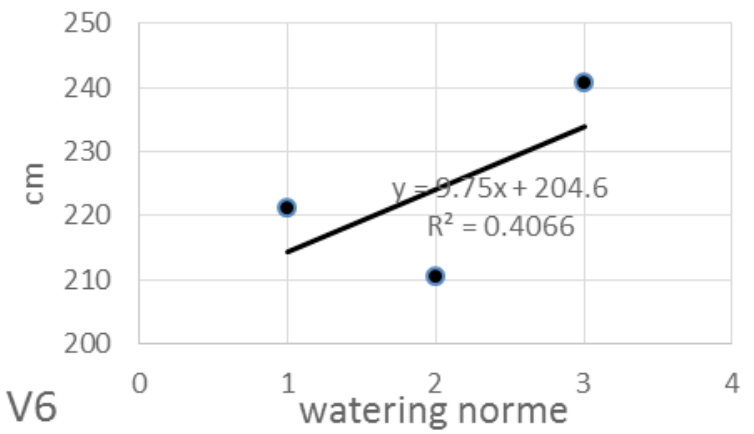

Fig. 9. The correlation between the plants' height and the watering norm $(\mathrm{a}, \mathrm{b}, \mathrm{c})$ on tomato crop - 5 mm Perlite substrate on 151 , average of 20142015

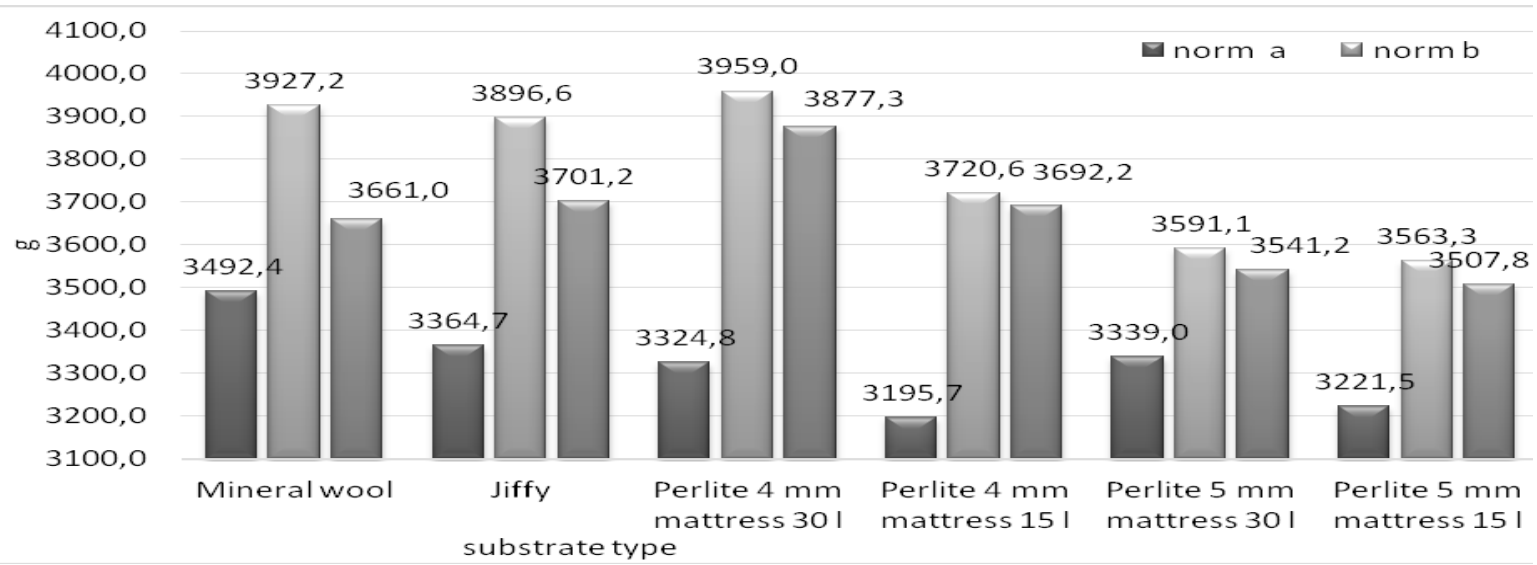

Fig. 10. Total productions obtained on Cyndel hybrid during the period of 2014-2015 according to the watering rate.
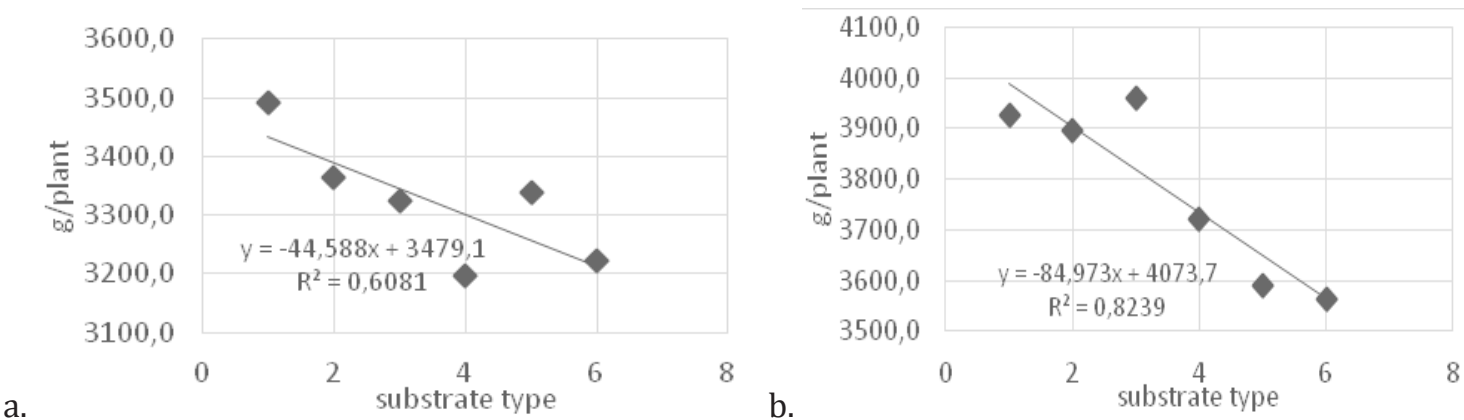

Figure 11. The influence of the type of substrate on the tomato production on plant in the case of the variant in which $(a)$ and $(b)$ watering norms were applied. 
In case of application norm b, it found that compared to the watering norms $a$ the yields were higher. These were between $111.24 \mathrm{t}$ / ha V6 and $119 \mathrm{t} /$ ha V3. Were noticed very significant differences at $\mathrm{V} 3$ and negative very significant at V6 compared to V1 - control (Table 6).

When applied to the watering $c$ were obtained higher production compared with norm $a$ and smaller than norm $\mathrm{b}$. The lowest production was obtained at V6 (107.47 t / ha) with $3.80 \mathrm{t} / \mathrm{ha}$ less and the highest production at V3 (116.96 t / ha) with $5.69 \mathrm{t} /$ ha compared to V1 control. Statistically the variants 2, 3 and 4 were recorded very significant differences and at the V6 negative significant difference (Tab. 7).

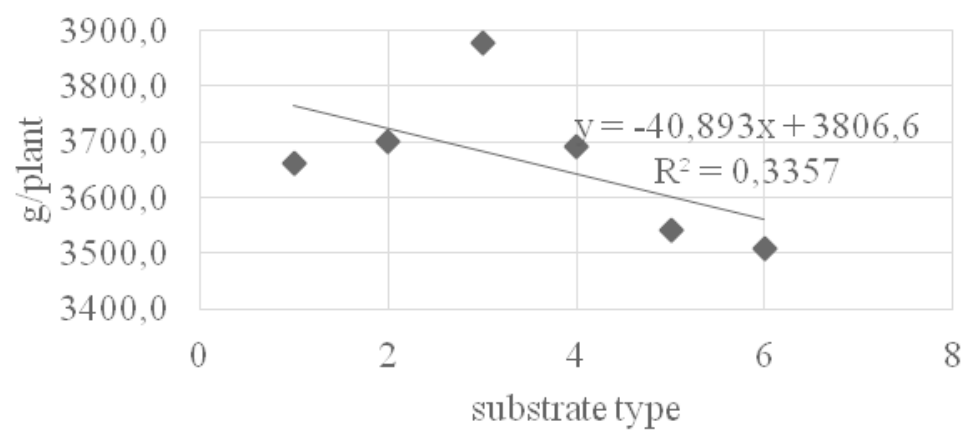

Fig. 12. The influence of the type of substrate on the tomato production on plant, in the case of the variant in which $c$ watering norm was applied.

Tab. 5. The synthesis of results regarding the total production in the greenhouse for norm a

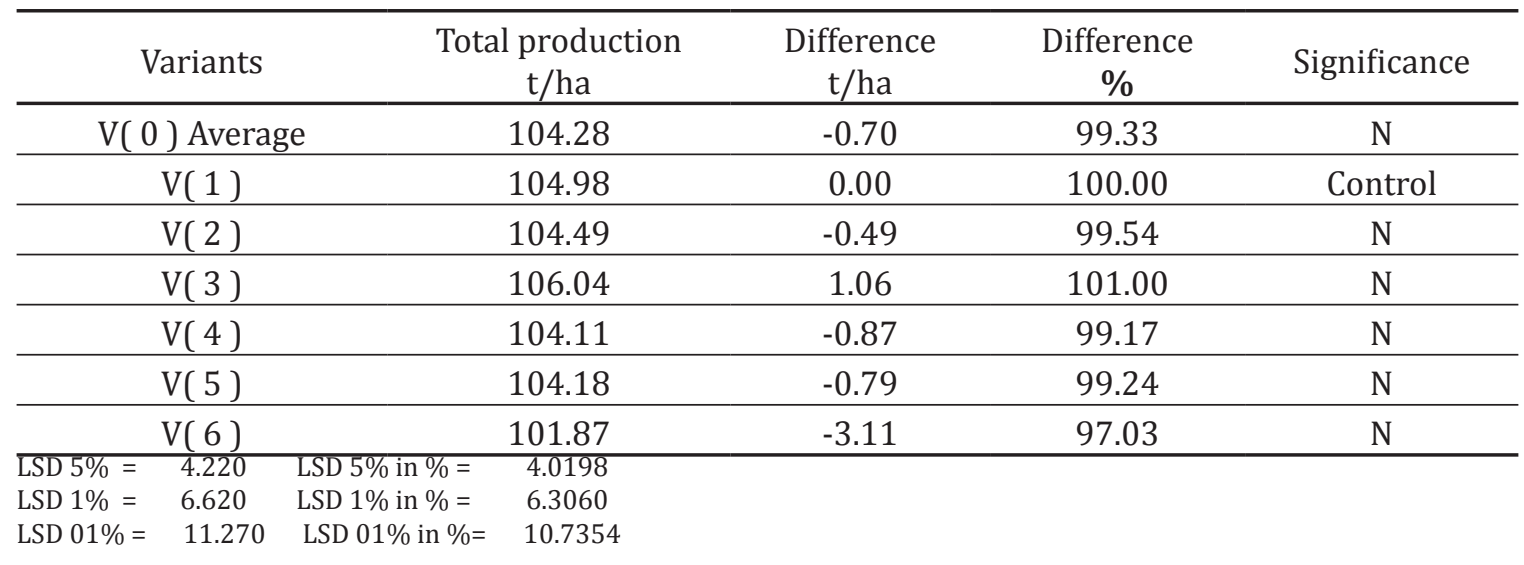

Tab. 6. The synthesis of results regarding the total production for $b$ watering norms

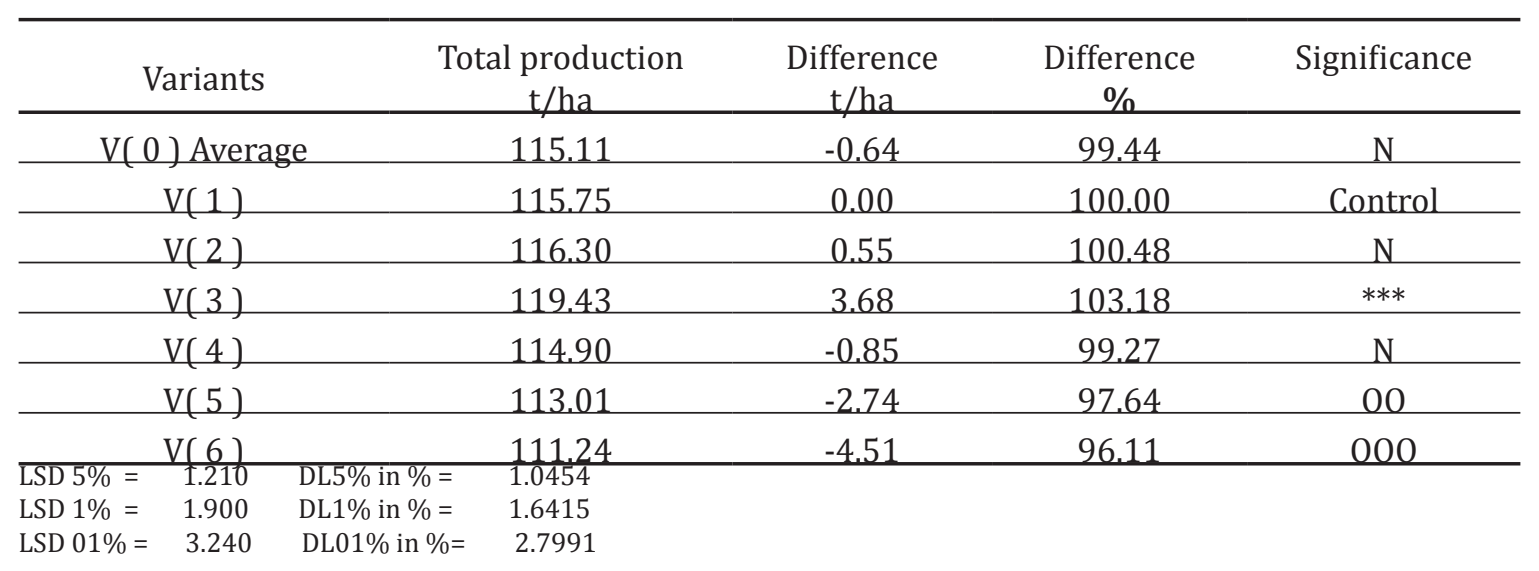


Tab. 7. The synthesis of results regarding the total production for $c$ fertigation norm

\begin{tabular}{|c|c|c|c|c|}
\hline Variants & $\begin{array}{c}\text { total production } \\
\text { t/ha }\end{array}$ & $\begin{array}{c}\text { Difference } \\
\mathrm{t} / \mathrm{ha}\end{array}$ & $\begin{array}{c}\text { Difference } \\
\% \\
\end{array}$ & Significance \\
\hline $\mathrm{V}(0)$ Average & 112.70 & 1.43 & 101.28 & $* *$ \\
\hline$V(1)$ & 111.27 & 0.00 & 100.00 & Control \\
\hline$V(2)$ & 114.65 & 3.38 & 103.03 & $* * *$ \\
\hline$V(3)$ & 116.96 & 5.69 & 105.12 & $* * *$ \\
\hline$V(4)$ & 114.38 & 3.11 & 102.80 & $* * *$ \\
\hline $\mathrm{V}(5)$ & 111.44 & 0.17 & 100.16 & $\mathrm{~N}$ \\
\hline $\mathrm{V}(6)$ & 107.47 & -3.80 & 96.58 & 000 \\
\hline \multicolumn{5}{|c|}{$\begin{array}{ll}\text { LSD 5 } \%=0.900 & \text { LSD 5 } \% \text { in } \%=0.8088 \\
\text { LSD 1 } \%=1.420 & \text { LSD 1 } \% \text { in } \%=1.2762\end{array}$} \\
\hline $\begin{array}{ll}\text { LSD } 1 \%=1.420 & \text { LSD } \\
\text { LSD } 01 \%=2.420 & \text { LSD }\end{array}$ & \multicolumn{4}{|c|}{$\begin{array}{l}\text { LSD } 1 \% \text { in } \%=1.2762 \\
\text { LSD } 01 \% \text { in } \%=2.1749\end{array}$} \\
\hline
\end{tabular}

\section{CONCLUSION}

In the present research work, we demonstrated that the biggest production of tomatoes was obtained $b$ watering norm 119.43 $\mathrm{t} / \mathrm{ha}$, on the perlite substrate mattresses of $30 \mathrm{l}$. The correlations that were conducted between the level of the total productions obtained according to the type of substrate and watering norm have indicated significant relations.

Acknowledgments: This paper was published under the frame of European Social Fund, Human Resources Development Operational Programme 2007-2013, project no. POSDRU/159/1.5/S/132765. Also, this work was supported by a grant of the Romanian National Authority for Scientific Research, CNDI - UEFISCDI, financed from project number PN-IIPT-PCCA-2011-3.2-1351 - Contract No.68/2012

\section{REFERENCES}

1. Drăghici EM, Pele M, Dobrin E (2013). Research concerning effects of perlite substrate on tomato in soilless culture. Scientific papers. Series B, Horticulture. Vol. LVII, 2013, p. 45-48. Print ISSN 2285-5653, CD-ROM ISSN 2285-5661, Online ISSN 2286-1580, 2285-5653, Bucureşti.

2. Fandim Al-Muhtaseb J A, Hussein M A (2008). Yield and Fruit Quality of Tomato as Affected by the Substrate in an Open Soilless Culture. Jordan Journal of Agricultural Sciences, Volume 4, No.1, 2008 p. 65.

3. Pardossi A, Carmassi G, Diara C, Incrocci L, Maggini R, Massa D (2011). Fertigation and Substrate Management in Closed Soilless Culture, Project Efficient use of imputs in protected horticulture, KBBE-2007-1-2-04, Dipartimento di Biologiadelle Piante Agrarie, Università di Pisa, Pisa.

4. 4. Traka-Mavrona EK, Maloupa E, Papadopoulos F, Papadopoulos A (1998). Response Of Greenhouse Tomatoes To Wastewater Fertigation In Soilless Cultivation. Acta Hortic. (ISHS) 458: p. 411- 416. 